\title{
Transposable Elements and Stress in Vertebrates: An Overview
}

\author{
Anna Maria Pappalardo ${ }^{1, *,+}$, Venera Ferrito ${ }^{1,+}$, Maria Assunta Biscotti ${ }^{2} \oplus$, Adriana Canapa ${ }^{2} \oplus$ and \\ Teresa Capriglione ${ }^{3}$ \\ 1 Department of Biological, Geological and Environmental Sciences-Section of Animal Biology "M. La Greca", \\ University of Catania, Via Androne 81, 95124 Catania, Italy; vferrito@unict.it \\ 2 Department of Life and Environmental Sciences, Polytechnic University of Marche, Via Brecce Bianche, \\ 60131 Ancona, Italy; m.a.biscotti@univpm.it (M.A.B.); a.canapa@univpm.it (A.C.) \\ 3 Department of Biology, University of Naples "Federico II", Via Cinthia 21—Ed7, 80126 Naples, Italy; \\ teresa.capriglione@unina.it \\ * Correspondence: pappalam@unict.it \\ + These authors contributed equally to this work.
}

Citation: Pappalardo, A.M.; Ferrito, V.; Biscotti, M.A.; Canapa, A.; Capriglione, T. Transposable Elements and Stress in Vertebrates: An Overview. Int. J. Mol. Sci. 2021, 22 1970. https://doi.org/10.3390/ ijms22041970

Academic Editor: Vladimir Trifonov Received: 29 January 2021

Accepted: 14 February 2021

Published: 17 February 2021

Publisher's Note: MDPI stays neutral with regard to jurisdictional claims in published maps and institutional affiliations.

Copyright: (c) 2021 by the authors. Licensee MDPI, Basel, Switzerland. This article is an open access article distributed under the terms and conditions of the Creative Commons Attribution (CC BY) license (https:// creativecommons.org/licenses/by/ $4.0 /)$.

\begin{abstract}
Since their identification as genomic regulatory elements, Transposable Elements (TEs) were considered, at first, molecular parasites and later as an important source of genetic diversity and regulatory innovations. In vertebrates in particular, TEs have been recognized as playing an important role in major evolutionary transitions and biodiversity. Moreover, in the last decade, a significant number of papers has been published highlighting a correlation between TE activity and exposition to environmental stresses and dietary factors. In this review we present an overview of the impact of TEs in vertebrate genomes, report the silencing mechanisms adopted by host genomes to regulate TE activity, and finally we explore the effects of environmental and dietary factor exposures on TE activity in mammals, which is the most studied group among vertebrates. The studies here reported evidence that several factors can induce changes in the epigenetic status of TEs and silencing mechanisms leading to their activation with consequent effects on the host genome. The study of TE can represent a future challenge for research for developing effective markers able to detect precocious epigenetic changes and prevent human diseases.
\end{abstract}

Keywords: transposable elements; vertebrates; environmental and dietary factors

\section{Introduction}

In the 1940s, when the Ac/Ds (activator/dissociation) transposon system was identified as the genetic basis for maize kernel variegation, Barbara McClintock proposed transposable elements (TEs) as genomic regulatory elements [1,2]. Later, Britten and Davidson suggested that repeated DNA components may affect gene expression through binding sites recognized by regulatory factors [3]. However, for several decades TEs were considered as molecular parasites, whose activity contributed to genetic instability by creating insertional mutations in genes, promoting double-strand breaks and interfering with the epigenetic status of genomes. By the end of the 2000s researchers abandoned this idea and an increasing number of papers has highlighted that TEs can be a source of genetic diversity and regulatory innovation, either promoting the emergence of novel genes or providing new regulatory regions $[4,5]$. Indeed, it is now recognized that the variability in number and composition of the TE families present in the genomes together with their ability to move represents one of the major forces for genome evolution [6].

Sequencing of eukaryotic genomes has revealed that a consistent fraction of repetitive DNA is represented by TEs. The mechanism used by these genetic elements to move and insert into various host genomic positions is called transposition. TEs can be grouped into two major categories based on the way they relocate in the genome: class I retrotransposons and class II DNA transposons. Retrotransposons relocate indirectly via RNA intermediates using a copy and paste mechanism. These elements are divided into Long Terminal Repeat 
(LTR) retrotransposons and non-LTR retrotransposons on the basis of the presence or absence of flanking sequences [7,8] (Figure 1a). LTR retrotransposons are long, about 250-600 bp, and are essential for transcription and insertion in new host genome position. LTR retrotransposons present the whole set of genes useful for transposition and thus are able to autonomously replicate and move themselves. In particular, their structure, constituted by genes encoding for gag proteins, reverse transcriptase, protease, $\mathrm{RNase} \mathrm{H}$, and integrase, is similar to the that of retroviruses. Ty1/Copia (Pseudoviridae), Ty3-gypsy-like (Metaviridae), and Bell/Pao are the three main families of LTR retrotransposons spread among vertebrates. Non-LTR retrotransposons include Long Interspersed Nuclear Elements (LINEs) and Short Interspersed Nuclear Elements (SINEs). As LTR retrotransposons also, LINEs are autonomous elements while SINEs are non-autonomous retrotransposons that use the retrotranscription machinery of other TEs [9].

Class II DNA transposons are wholly DNA-based elements (found in both prokaryotes and eukaryotes) that can directly relocate autonomously from DNA to DNA, via a cut and paste mechanism. However, about a decade ago, analysis of a large amount of eukaryotic genome sequences led to the discovery of a new type of DNA transposons called Polintons (known also as Mavericks) and Helitrons [10-13]. Most of the Polintons encode homologs of major and minor icosahedral viruses, capsid proteins and several enzymes such as integrase, ATPase, protease, and polymerase. Helitrons encode for Rep/Helicase protein having endonuclease and helicase activity and are able to move by rolling-circle replication mechanism [10]. Differently from these DNA transposons, Miniature Inverted-repeat Transposable Elements (MITEs) are non-autonomous elements less than $800 \mathrm{bp}$ long with terminal inverted repeats [6] (Figure 1a).

The various classes of TEs are differently represented in terms of both quantity and quality across all domains of life. For example, $45 \%$ of the repeated elements in the human genome is represented by retrotransposons [44] while plant genomes may hold a higher proportion of transposable element-derived DNA [45,46]. Indeed, more than $80 \%$ of the genomes of barley, wheat, and maize consist of DNA transposons [47]. All classes of TEs are present in the Arabidopsis genome, while Saccaromyces cerevisiae contains only members of the LTR retrotransposon family. A wide variety, present in limited numbers, of LTR and nonLTR retrotransposon families are present in the genome of Drosophila. Conversely, a very large number of few related retroelements from the IAP (Intracisternal-A-particle) (LTR), LINE1, and SINE B1 (non-LTR) retrotransposon families dominate the mouse genome [48]. The remarkable ability of TEs to colonize genomes was further confirmed by the recent discovery of TEs in giant virus DNA [49].

Vertebrates are the sister group of urochordates and their common ancestor diverged from cephalochordates about 500 Mya [50]. Vertebrates experienced innovations and adaptations that allowed the extraordinary evolutionary success of this group. Several bursts of TEs, belonging to different families, have affected the genome of vertebrates over this time $[51,52]$ and the subsequent exaptation of new TE insertions may have conditioned genome evolution and provided raw material for transcription factor binding sites. Indeed, it is not negligible that an increasing amount of evidence supports the origin of transcription factor binding sites and non-coding RNAs from TEs [53-55]. In humans, about $20 \%$ of conserved regulatory sequences have been co-opted from TEs [56].

Epigenetic mechanisms such as DNA methylation and histone modifications, as well as small RNAs and sequence-specific repressors such as KRAB zinc-finger proteins, regulate the activity of TEs, generally silencing them. TE reactivation and retro-transposition have been reported in the development of human pathogenesis and environmental stressors seem to play a major role in determining these events. Therefore, TEs are more than junk and have a significant role in maintaining the genome structure and stability, but they are also involved in the onset of diseases and, in this context, an important open question is to what extent diet could affect TEs mediated gene expression. In light of these premises, in this review, we present an overview of the impact of TEs on vertebrate genomes, report the silencing mechanisms adopted by host genomes to regulate TE activity, and finally we 
explore the effects of environmental factor exposures on TE modulation in mammals which is the most studied group among vertebrates.

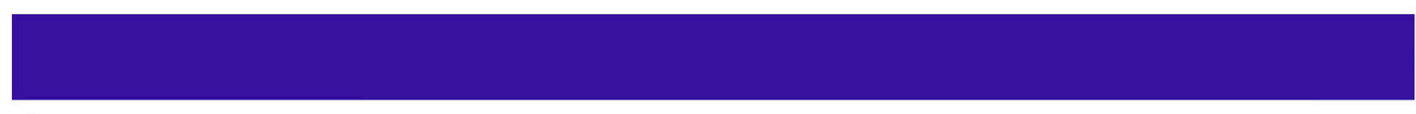

a

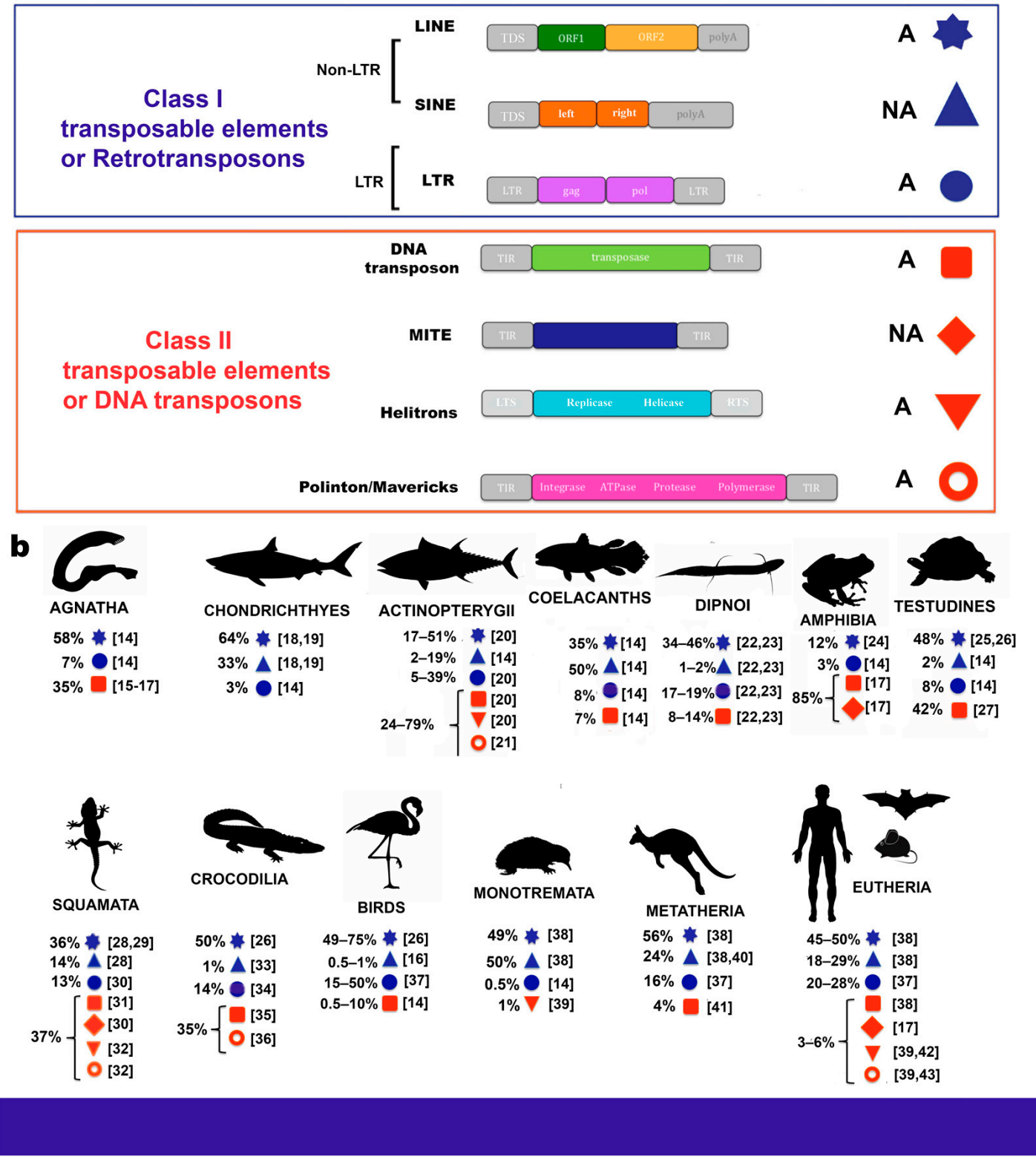

Figure 1. Classification (a) and distribution of transposable elements (TEs) in vertebrates (b) [14-43]. In panel (a), autonomous elements are indicated with capital letter A, while non-autonomous elements with capital letters NA. Symbols attributed to each transposable element type are reported on the right. ORF: open reading frame; polyA: polyadenylation site; gag: gene coding for the structural protein; pol: gene coding for reverse transcriptase, ribonuclease $\mathrm{H}$, and integrase. TIR: terminal inverted repeat; TSD: target site duplication. LTS: left terminal sequence; RTS: right terminal sequence. Numbers in square brackets indicate references; the percentages indicate the relative amount of each TE type in different vertebrate genomes based on data from Chalopin et al. [15], Meyer et al. [22], and Wang et al. [23].

\section{TEs in Vertebrate Genomes}

Innovations in cells, tissues, organs, and structures have been responsible for the evolution of new species in vertebrates. Many of these modifications have been linked to 
TE activity and in particular to exaptation events that contribute to the creation of new genes and regulatory elements [57]. The comparison with cephalochordates, the living organisms closest to the chordate ancestor, has highlighted that vertebrate genomes have experienced a general decrease of TEs in terms of quantity and diversity [58]. However, not clear is the condition of organisms having large genome size such as lungfish and salamanders, for which genome assemblies are absent or limited and thus information on TEs at genome level are rather scarce. Overall the various classes of TEs are differently represented across vertebrate lineages and some TE superfamilies are widespread among vertebrate lineages, while others present a patchy distribution indicating that events of loss or gain occurred during evolution [14].

For Agnatha, genome assemblies are currently available for only three species: the hagfish Eptatretus stouti and the lampreys Lethenteron camtschaticum and Petromyzon marinus. TEs have been investigated only in P. marinus in which these elements constitute the $34.7 \%$ of the assembled sequences and are mainly dominated by LINE retroelements followed by DNA transposons $[14,59,60]$. Among Gnatosthomata, and also Chondrichthyes, data available are restricted to a single species, the elephant shark Callorhinchus milii [61], in which TE-derived DNA makes up $42 \%$ of the total sequenced genome with a prevalence of LINEs followed by SINEs. TE content is highly variable in fish, ranging from $5 \%$ to $56 \%$ of the genome (Figure 1b). Moreover, they present the highest TE diversity among vertebrates, a feature that is maintained also in organisms with small genomes as in Tetraodontiformes. The mobilome of fish is predominantly represented by DNA transposons and LINEs, whereas SINEs are the least abundant. However, in the non-teleost Lepisosteus oculatus TE content is enriched by retroelements [14]. Furthermore, a statistically significant correlation has been detected between TE content and the size of fish genomes [62]. In teleost, lineagespecific TEs such as Rex1, Rex3, and Rex6 elements have received special attention due to the role they have likely played in the evolution of teleost fish [63-66]. Recently, a novel database (FishTEDB) has been developed including 27 bony fishes, 1 cartilaginous fish, 1 lamprey, and 1 lancelet to provide a good basis for TE functional studies and promote transposable element research [67].

It is interesting that the condition of coelacanths shows some very active TE families despite their slow evolving genome [68,69]. The mobilome of these basal sarcopterygians, corresponding to about $20 \%$ of their genome, is dominated by SINE retroelements [14].

The huge size of the lungfish genome has long represented a challenge for assembly procedures. However, the recent genome sequencing of the Australian lungfish Neoceratodus forsteri and the West African lungfish Protopterus annectens allowed the gap in our knowledge about this taxonomic group to be filled. The analysis in $N$. forsteri revealed that about $90 \%$ of the assembly is made up of TEs [22] while $61.7 \%$ in P. annectens [23]. Both analyses showed that LINE retrotransposons represent the major amount in agreement with a previous report [70] and the elements are also highly active in P. annectens [62].

Similarly, Amphibia is a clade characterized by organisms with large genomes as the case of some caecilians with approximately $14 \mathrm{~Gb}$ up to extreme values in salamanders with about $120 \mathrm{~Gb}$ [71]. These differences have been attributed to various factors such as the presence of longer introns [72] and a low rate of DNA elimination [73] but also to the variable propensity towards TE accumulation.

Indeed, the two Xenopus tropicalis and Nanorana parkeri, having genomes of $1.5 \mathrm{~Gb}$ and $2.3 \mathrm{~Gb}$ respectively, differ in their TE content of about $25 \%$ for the Western frog and about $50 \%$ for the Tibetan frog [74]. This incongruence was related to the expansion of DNA transposons in X. tropicalis, in particular of Kolobok-T2 elements and of LTR retrotransposons in N. parkeri, in particular of Gypsy elements [74]. These retroelements have been found to be really abundant also in the highly repetitive genome of the strawberry poison frog Oophaga pumilio [75] and have been proposed also as responsible for the gigantism of salamanders [73]. Instead, the recent analysis performed on the caecilian Ichthyophis bannanicus genome evidenced an abundance of Dictyostelium intermediate repeat sequence (DIRS) and LINE/Jockey elements [76]. The genomes of non-bird reptiles examined to date 
showed a TE content ranging from $20 \%$ to $30 \%$ with a prevalence of LINE retroelements and DNA transposons [32,77-79]. Moreover, a decrease of TE superfamily richness was reported for this taxon indicating that a progressive reduction of TE diversity occurred during sarcopterygian evolution [14]. This aspect is extreme in the small genomes of birds which present low TE copy number and diversity dominated mainly by CR1 elements [80]. However, the recent study of Suh et al. [81] demonstrated that the flycatcher and the zebra finch lineages exhibit a high diversity of novel, lineage-specific retrovirus-like LTR retrotransposons.

The complete DNA sequencing of whole mammalian genomes has shown that at least $46 \%$ of human DNA, $31 \%$ of canine DNA, and $37 \%$ of mouse DNA are derived from TEs [82]. In most mammalian genomes a large proportion of TEs consists of LINE and SINE retrotransposons, more limited are LTR retrotransposons and minimal DNA transposon. Among LINE elements, LINE1 (L1) is the most active in the human genome as well as SINE elements [83]. The mammalian TE repertoire differs for the diversity of SINE retroelements that are order/family-specific and emerged independently multiple times [84]. Although it has been highlighted that human DNA transposons have accumulated mutations rendering them immobile, potentially active DNA transposons have been identified in the genome of bat species $[38,82]$.

\section{Regulation Mechanisms of TE Activity}

Changes of genome size and composition are related to TE mobilization. Although the trigger involved in TE induction is not completely understood, it is clear that the transposition process can cause deleterious effects in the host genome with consequent reduction of fitness and thus also of TE replication and propagation. Therefore, strategies to minimize the negative impact of TE mobilization have been developed. Some TEs have evolved self-regulatory mechanisms controlling their own copy numbers $[85,86]$. In this regard, a self-regulatory mechanism has been described for DNA transposons of the superfamily Tc1/mariner, the so-called overproduction inhibition (OPI). The increase of copy number leads to an increase of synthetized transposases that in turn determine a higher transposon activity. The OPI mechanism consists in the formation of inactive or less inactive transposase oligomers to decrease transposition [87]. On the other side, the controlling TE mechanisms from the host are: (i) DNA methylation, (ii) histone modifications, (iii) regulation by small RNAs, (iv) sequence-specific repressors such as the recently profiled Krüppel-associated box (KRAB) zinc-finger proteins [88-90], and (v) sequence editing by apolipoprotein B mRNA editing enzyme, catalytic polypeptide-like (APOBEC) (Figure 2).

DNA methylation is the most widely adopted mechanism for silencing TEs and consists of the addition of methyl groups to DNA. In particular, a DNA methyltransferase catalyzes the transfer of a methyl group from S-adenyl methionine to the fifth carbon of a cytosine residue to form 5-methylcytosine. This process is connected with the cytosineguanine dinucleotide (CpG) sites. It is not surprising that about $90 \%$ of methylated $\mathrm{CpG}$ sites in the mammalian genome are found in repeated elements and above all in TEs such as SINEs and LINEs [91]. Besides this strategy, recent investigations have pointed out the key role of histone modifications as one of the most important epigenetic mechanisms in regulating TE activity [92]. In fact, changes at post-translational level of $\mathrm{N}$-terminal histone tails such as acetylation, methylation, and phosphorylation can prevent the accessibility of DNA to regulatory factors and/or polymerase complexes by affecting inter-nucleosomal interactions, chromatin structure, and finally gene expression. 


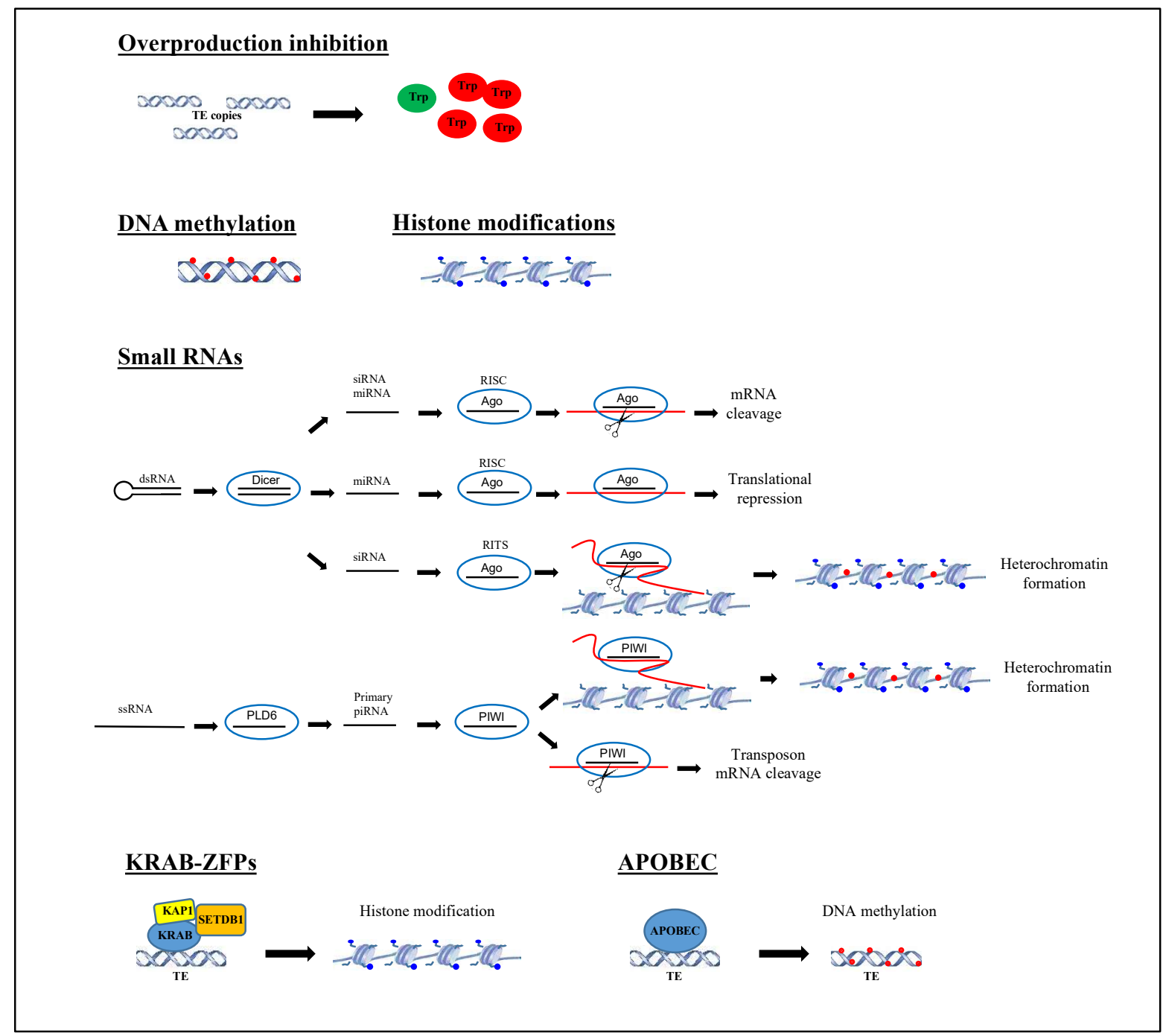

Figure 2. Transposable element silencing mechanisms. The main mechanisms involved in silencing transposable elements are represented. For details see text at paragraph 3. Active transposase is represented with green ovals; inactive transposases are represented with red ovals; modifications at DNA level are represented with small red circles; modifications at histone tails are represented with small blue circles; a red line indicates mRNA; a long red curved line indicates nascent RNA.

Another conserved mechanism of silencing of TEs includes the control by regulatory non-coding RNAs (ncRNAs), such as microRNAs (miRNAs), short interspersed RNAs (siRNAs), and PIWI-interacting RNAs (piRNAs). These ncRNAs differ for number of nucleotides, origin, and function. miRNAs and siRNAs have a length of about 21-25 nucleotides and are generated from double-stranded RNA precursors cleaved by Dicer. miRNAs and siRNAs become part of a cytoplasmatic RNA-induced silencing complex (RISC) including Argonaute subfamily proteins, and are able to bind target mRNAs and prevent translation [93]. siRNAs are part of the RNA-induced transcriptional silencing complex (RITS) containing an argonaute-family protein. The small RNA is used to target nascent RNAs still attached to RNA polymerase and DNA. The transcripts are cleaved and the involved DNA regions undergo modifications of chromatin as the methylation at lysine 9 of histone H3 and DNA methylation [94]. Mechanisms that restrict TE expression and mobilization are likely to be particularly important in germ cells and piRNAs represent the master regulators in vertebrates $[95,96]$. piRNAs have a size of about 24-31 nucleotides and are associated with PIWI subfamily proteins. The precursors of piRNAs are long singlestranded RNAs and for this reason they cannot be processed by Dicer. These precursors are cleaved by an endonuclease Phospholipase D Family Member 6 (PLD6) producing the $5^{\prime}$ 
end of primary piRNAs and then loaded into Piwi proteins before again being trimmed to generate the $3^{\prime}$ end of the mature piRNAs [97]. Moreover a ping-pong pathway involving PIWI proteins is responsible for the production of secondary piRNAs. Silencing of TEs can take place transcriptionally through histone and DNA methylation of TEs, as well as posttranscriptionally by targeted TE transcript degradation [57,98]. The Krüppel-associated box domain zinc finger proteins (KRAB-ZFPs) and the APOBEC enzymes represent vectors for these types of TE regulation. The former are a family of transcriptional regulators, that control TEs in higher vertebrates including humans acting during embryonic development [53]. They recognize TEs in a sequence-specific manner and recruit the co-factor KAP1, and the histone methyltransferase SETDB1 that is involved in the deposition of H3K9me3 modification. After this step, TEs are de novo methylated at DNA level and this epigenetic change persists in somatic and germ cells [99].

A wealth of data indicates that the evolutionary history of KRAB-ZFPs is strictly linked to that of TEs. Indeed, TEs can evade detection by host KRAB-ZNFs by acquiring mutations and consequently the host repressor mechanisms need to evolve rapidly in order to maintain genome integrity. Two models have been hypothesized to explain the relationship between KRAB-ZFPs and TEs. The first is consistent with an "arms race model" stating that the major role of KRAB-ZFPs is the recognition and transcriptional silencing of TEs as recently demonstrated by large scale ChIP-seq studies and loss-of-function experiments [87]. However, this model has been considered too simplistic to justify the selection of KRAB-ZFPs genes. On the other hand, the "domestication model" introduces the concept that TE sequences could be co-opted to serve cellular functions beneficial to the host organism [100]. For this reason, a KRAB-ZFP recognizing a TE could either silence it, modify its regulatory activity, or leave it intact [90]. The APOBEC enzymes, most of which are potent DNA cytidine deaminases, through DNA editing, convert cytosines residues to uracils (C-to-U) in a wide variety of parasitic elements, including many retroviruses [81]. This mechanism leads to an accumulation of mutations that render TEs inactive [101]. However, it has been demonstrated that in a few cases a preferential retention of edited elements bearing high mutation loads could give rise to a beneficial sequence that is positively selected and retained in active genomic regions [81].

\section{How Environmental Stresses Modulate TE Activity}

TE activation in response to environmental stress was first proposed by Barbara McClintock [2], who believed that controlling elements (TEs) permitted the genome to respond more flexibly to environmental shocks and stresses. The hypothesized mechanism was the association of transposition with heterochromatin and the subsequent alteration of gene expression through mobilization of heterochromatin domains [2].

In general, environmental stressors, natural or of anthropogenic nature, have been shown to alter epigenetic modifications such as DNA methylation and histone modifications, and the expression of small non-coding RNAs [102,103]. Failure of silencing mechanisms results in TE reactivation that causes genomic instability with potentially neutral, harmful, or beneficial effects on the host genome [104,105]. Stress-activated TEs can provide raw material from which to generate new genes, or disseminate regulatory elements to create stress-inducible genes and/or networks, or act directly on specific genes. The activation of TEs in response to stress conditions has been suggested to have an adaptive role since transposition generates a higher mutation rate that causes an increase in genetic variability on which natural selection can act to generate advantageous functions for species to survive stressful situations. In mammals, the proopiomelanocortin gene (Pomc) is a gene expressed in a group of neurons of the hypothalamus and is involved in the regulation of food intake and energy balance. This gene is regulated by two enhancers originated from independent exaptation events of two unrelated retrotransposons. It is conceivable that these events occurred in response to periods of climate change during mammal evolution conferring an adaptive advantage through the inhibition of foraging behavior in the presence of predators and escaping after injury [106]. 
The exposition to numerous environmental stresses, such as exposure to pollution, terrestrial and space radiation, temperature changes, endrocrine distruptors, and physiological and psychological stresses, determines most frequently the hypomethylation of L1 retroelements and ERVs and the hypermethylation of Alu elements with consequently cancer and disease development in mammals [107]. Alu retroelements are hypomethylated in the peripheral blood cells in the case of exposure to persistent organic pollutants (many of which are endocrine disruptors) [108] and in tibia in the case of exposure to lead [109].

Exposure to stressful conditions can cause not only changes in TE transcription but also in transposition rate as in the case of heavy metal exposure. Indeed, arsenic [110] and mercury [111] can cause mobilization of L1 retroelements.

In mammals, the L1 element is one of the most abundant retrotransposons whose activity is responsible for a variety of disorders, from hemophilia A [112], diabetes, and $\beta$-thalassemia $[113,114]$ to cancer [115-118]. Under normal conditions, L1 is silenced by the longevity regulating protein Sirtuin 6 (SIRT6) that keeps its promoter in a heterochromatic state, but under genotoxic stressors or during aging this mechanism fails and L1 is transcribed contributing to the development of age-related diseases [119]. Dysregulation of transposable elements has also been related to a variety of nervous system disorders [120-122] and physiological and psychological stresses have been proposed as a cause of TE activation [123]. The dynamics of the N(6)-methyladenine (6mA), a modified DNA adenine found in mammalian cells, have been examined in the mouse brain in response to environmental stress. A correlation between the gain of $6 \mathrm{~mA}$ on intergenic regions and the downregulation of $90.4 \%$ of LINE retrotransposon expression has been found upon stress [124]. The regulatory effect of environmental stress on retrotransposon expression in the brain has been demonstrated also by Hunter et al. [125]. According to their findings, the initial activation of TEs can be followed by the repression of specific TEs, such as intracisternal A particle endogenous retrovirus elements and B2 short interspersed elements, to limit genomic instability. In the rat hippocampus, acute stress increases levels of the repressive histone $\mathrm{H} 3$ lysine 9 trimethylation (H3K9me3) at transposable element loci, correlated also with an upregulation of Suv39h2 gene encoding for the enzyme involved in the deposition of this epigenetic mark. The specificity of this TE regulatory mechanism in the hippocampus has been related to the presence of pyramidal cells involved in long-term memory whose instability would reduce the ability to maintain their functions [126].

Response to heat-shock mediated by TEs is one of the best stress statuses studied in vertebrates. In humans in the presence of heat stress the expression of some genes decreases while that of Alu elements increases. Indeed, it has been demonstrated that mRNAs produced from SINEs act in trans repressing the transcription by directly binding RNA polymerase II forming stable complexes at promoters [127]. In mice, the chaperone heat-shock protein HSP90 forms a complex with KAP1 protein to repress the regulatory influence of endogenous retroviruses on neighboring genes. Under stress conditions, this function is compromised and an upregulation of nearby genes by ERVs is detected [128]. This kind of stress can cause also both up- and downregulation of gene expression after TE activation. Indeed, the mRNA produced from B2 SINE retrotransposon normally binds stress-responsive genes, decelerating the progression of RNA polymerase II and thus reducing their expression. However, stress induces the recruitment of EZH2 protein that in turns cleaves B2 RNAs causing an increased expression of stress genes. At the same time, B2 RNA molecules bind other genes downregulating them [129].

In humans in vitro, in vivo, and epidemiological studies evidence that TEs are sensitive endpoints for detection of the effects caused by environmental stresses suggesting their use as biomarkers and/or targets for therapeutic treatment and prevention of diseases [107].

Overall, a specificity seems to exist between TEs and stress condition [104] but the behavior of stress-induced TEs seems to depend on the type of stress and TE [130]. However, several open questions remain to be elucidated concerning the relationship between TEs and stress as to why some TEs are upregulated and others downregulated or why some TE families are more prone to be activated than others [130]. 


\section{How Nutrition Modulates TE Activity}

Since the pioneering investigations of Wolf et al. [131], Morgan et al. [132], and Waterland and Jirtle [133], environmental epigenomics has become a prolific field of research. These authors showed that maternal dietary supplementation with methyl donors such as folic acid, choline, and betaine caused a shift in the coat color of agouti mice offspring from yellow to brown. Furthermore, they identified the DNA methylation of a transposable element upstream of the agouti gene, as a molecular basis for the observed color shift. Since then, a series of research has led to the rise of nutritional epigenomics as a sub-discipline of environmental epigenomics, focused on the role of dietary factors (micro-nutrients, macro-nutrients, and non-nutrient dietary components) on epigenetic modifications and disease risk [134]. Additional evidence for the diet-dependent epigenetic repression of TEs has been found.

For example, the study of Dolinoy et al. [135] demonstrated the epigenetic effects of prenatal exposure to bisphenol A (BPA) in mice leading to yellow fur, obesity, diabetes, and tumorigenesis. In particular, the authors highlighted that maternal BPA exposure reduces DNA methylation at nine $\mathrm{CpG}$ sites located immediately upstream in the cryptic promoter region of the $A^{v y}$ IAP retrotransposon. More importantly, the authors discovered that maternal nutritional supplementation with methyl donors or genistein counteracts BPA-induced hypomethylation restoring the coat color distribution in BPA-exposed offspring toward the methylated pseudoagouti phenotype. The covalent binding of the vitamin biotin to lysine-12 in histone H4 (H4K12bio), mediated by holocarboxylase synthetase (HCS), has been demonstrated to be responsible for the repression of LTR retrotransposons in human and mouse cell lines [136]. The authors showed that repression of LTR retrotransposons depends on crosstalk between H4K12bio and methylation marks and proposed a model in which three nutrient-dependent repression marks (cytosine methylation, H4K12bio, and H3K9me2) synergize in the repression of LTR retrotransposons. Additionally, Kuroishi et al. [137] clearly demonstrated that biotinylation is a rare but natural histone modification in humans. The ability of natural stilbenoids deriving from resveratrol to inhibit the HIV-1 integrase, a protein involved in the integration mechanisms of retroviruses, and the eukaryote MOS- 1 transposase, a protein responsible for the mobility of the mariner group transposable elements, have been demonstrated in vitro and in vivo by Pflieger et al. [138]. By assessing the efficacy of two resveratrol dimers and fourteen stilbenoids against the two enzymatic models, the authors found a different activity of the molecules, some of which were active against both proteins while others were specific for one of the two models, suggesting that specific intermediate nucleocomplexes of the reactions could be targeted by the compounds. The results obtained by Agodi et al. [139] demonstrated that a dietary pattern characterized by low fruit consumption and folate deficiency, not adherent to the Mediterranean dietary pattern, was associated with LINE-1 hypomethylation and with cancer risk in 177 healthy women. The authors suggest that leukocyte LINE-1 methylation may serve as a biomarker for dietary interventions designed to reduce the risk of cancerous and precancerous conditions. Furthermore, Barchitta et al. [140] examined a sample of 299 healthy women and demonstrated for the first time the inverse association between adherence to the Mediterranean diet and exposure to particulate matter having an effective aerodynamic diameter smaller than $10 \mu \mathrm{m}$ (PM10) with LINE-1 methylation. More specifically, they showed that the monthly PM10 exposure level was significantly and inversely associated with LINE-1 methylation which, on the contrary, was significantly and positively associated with adherence to the Mediterranean diet measured through the Mediterranean Diet Score. Interestingly, studies by Green et al. [141] additionally demonstrated that lifespan-extending diets in mice largely repressed the expression of miRNAs, lncRNAs, and TEs. In particular, the authors characterized lifespan-related liver transcriptome changes mediated by different dietary intervention regimens. They found that coding genes, repeat elements and miRNAs were regulated by dietary interventions and were highly correlated with lifespan and aging. The authors suggested that a crosstalk exists among miRNAs, chromatin remodelers, and TEs: they identified specific miRNAs 
(miR-34a, miR-107, and miR-212-3p) targeting Chd1, a chromatin remodeler gene, able to both activate transcription and repress it. On one hand Chd1 promotes the expression of mRNA positively related with lifespan, on the other it represses transposable elements.

\section{Conclusions}

Transposable elements make genomes dynamic and are responsible for their evolution. It is known that the quantitative impact of total TEs as well as of specific TE types varies in different lineages. Our comparative analysis of TE accumulation in vertebrate genomes revealed that information is mainly focused on mammals, while for many other groups information on TEs is rather scarce or even absent due to the lack of available genome assemblies. Moreover, in the last decade, a significant number of papers have been published highlighting a correlation between TE activity and exposition to environmental stresses and dietary factors. In general, they cause changes in DNA methylation, histone modifications, and in the expression of small non-coding RNAs. These modifications determine the failure of silencing mechanisms with consequent reactivation of TEs. This activity can have an adaptive role generating a higher mutation rate that causes an increase in genetic variability on which natural selection can act to generate advantageous functions for species to survive stressful situations. On the contrary, transposition can have deleterious effects in the host genome and cause the onset of diseases. Certainly, many questions remain to be addressed, such as to unveil the TE diversity and function in a wider range of species than that known today, to detect the wide variety of propagation mechanisms of TEs within genomes, and finally to understand to what extent diet could effect TEs mediated gene expression. The deep knowledge of these aspects will allow the interplay between TE intrinsic characteristics, host biology, and response to the environmental factors (Figure 3) to be correctly evaluated.

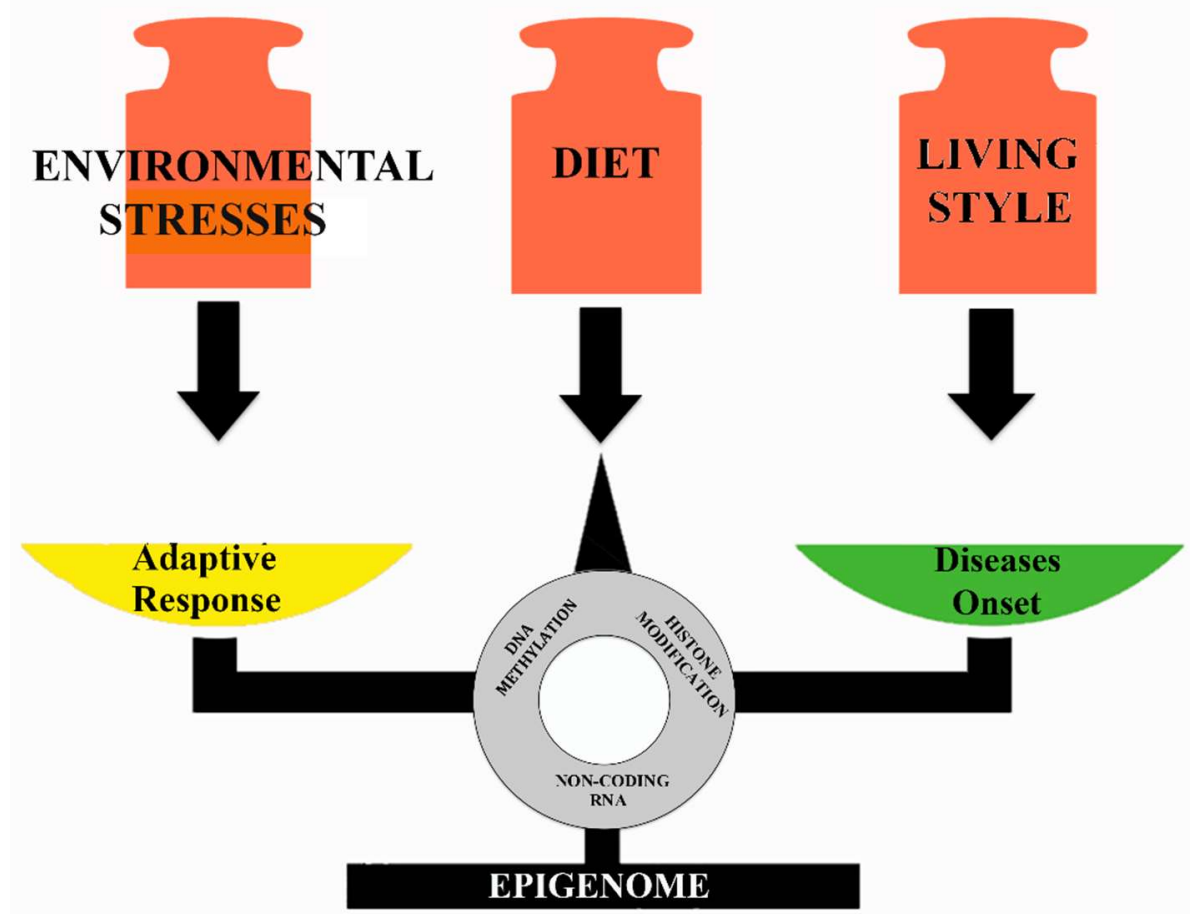

Figure 3. Environmental and nutritional epigenetic effects on the health status.

Author Contributions: Conceptualization T.C., A.M.P., V.F.; writing-original draft preparation A.M.P., M.A.B., A.C., V.F.; writing-review and editing A.M.P., M.A.B., A.C., V.F. All authors have read and agreed to the published version of the manuscript.

Funding: This research received no external funding. 
Acknowledgments: This review was conceived by our dear colleague and friend Teresa Capriglione. She suddenly passed away during the writing of the manuscript leaving us with a great void. She was a brilliant scientist and a lovely friend. We will cherish her memory forever.

Conflicts of Interest: The authors declare no conflict of interest.

\section{References}

1. McClintock, B. Mutable loci in maize. In Annual Report of the Director of the Department of Genetics; Carnegie Institution of Washington Yearbook, Ed.; Cold Spring Harbor: New York, NY, USA, 1947-1948; pp. 155-169.

2. McClintock, B. The significance of responses of the genome to challenge. Science 1984, 226, 792-801. [CrossRef]

3. Britten, R.J.; Davidson, E.H. Gene regulation for higher cells: A theory. Science 1969, 165, 349-357. [CrossRef]

4. Jordan, J.I.; Rogozin, I.B.; Glazko, G.V.; Koonin, E.V. Origin of a substantial fraction of human regulatory sequences from transposable elements. Trends Genet. 2003, 19, 68-72. [CrossRef]

5. Zhou, L.; Atkinson, P.W.; Hickman Dyda, F.A.B.; Craig, N.L. Transposition of hAT elements links transposable elements and V(D)J recombination. Nature 2004, 432, 995-1001. [CrossRef]

6. Feschotte, C.; Pritham, E.J. DNA transposons and the evolution of the Eukaryotic Genomes. Annu. Rev. Genet. 2007, 41, 331-368. [CrossRef]

7. Wicker, T.; Sabot, F.; Hua-Van, A.; Bennetzen, J.L.; Capy, P.; Chalhoub, B.; Flavell, A.; Leroy, P.; Morgante, M.; Panaud, O.; et al. A unified classification system for eukaryotic transposable elements. Nat. Rev. Genet. 2007, 8, 973-982. [CrossRef] [PubMed]

8. Makałowski, W.; Gotea, V.; Pande, A.; Makałowska, I. Transposable Elements: Classification, identification, and their use as a tool for comparative genomics. Methods Mol. Biol. 2019, 1910, 177-207. [PubMed]

9. Kramerov, D.A.; Vassetzky, N.S. Origin and evolution of SINEs in eukaryotic genomes. Heredity 2011, 107, 487-495. [CrossRef] [PubMed]

10. Kapitonov, V.V.; Jurka, J. Rolling-circle transposons in eukaryotes. Proc. Natl. Acad. Sci. USA 2001, 98, 8714-8719. [CrossRef] [PubMed]

11. Kapitonov, V.V.; Jurka, J. Self-synthesizing DNA transposons in eukaryotes. Proc. Natl. Acad. Sci. USA 2006, 103, 4540-4545. [CrossRef]

12. Bao, W.; Kapitonov, V.V.; Jurka, J. Ginger DNA transposons in eukaryotes and their evolutionary relationships with long terminal repeat retrotransposons. Mob. DNA 2010, 1, 3. [CrossRef]

13. Arkhipova, I.R.; Yushenova, I.A. Giant transposons in Eukaryotes: Is bigger better? Genome Biol. Evol. 2019, 11, 906-918. [CrossRef] [PubMed]

14. Chalopin, D.; Naville, M.; Plard, F.; Galiana, D.; Volff, J.-N. Comparative analysis of transposable elements highlights mobilome diversity and evolution in vertebrates. Genome Biol. Evol. 2015, 7, 567-580. [CrossRef] [PubMed]

15. Kuraku, S.; Qiu, H.; Meyer, A. Horizontal transfers of Tc1 elements between teleost fishes and their vertebrate parasites, lampreys. Genome Biol. Evol. 2012, 4, 929-936. [CrossRef]

16. Zhang, H.-H.; Feschotte, C.; Han, M.-J.; Zhang, Z. Recurrent horizontal transfers of Chapaev transposons in diverse invertebrate and vertebrate animals. Genome Biol. Evol. 2014, 6, 1375-1386. [CrossRef]

17. Sang, Y.; Gao, B.; Diaby, M.; Zong, W.; Chen, C.; Shen, D.; Wang, S.; Wang, Y.; Ivics, Z.; Song, C. Incomer, a DD36E family of Tc1/mariner transposons newly discovered in animals. Mob. DNA 2019, 10, 45. [CrossRef]

18. Ogiwara, I.; Miya, M.; Ohshima, K.; Okada, N. Retropositional parasitism of SINEs on LINEs: Identification of SINEs and LINEs in elasmobranchs. Mol. Biol. Evol. 1999, 16, 1238-1250. [CrossRef]

19. Ogiwara, I.; Miya, M.; Ohshima, K.; Okada, N. V-SINEs: A new superfamily of vertebrate SINEs that are widespread in vertebrate genomes and retain a strongly conserved segment within each repetitive unit. Genome Res. 2002, 12, 316-324. [CrossRef]

20. Rhee, J.S.; Choi, B.S.; Kim, J.; Kim, B.M.; Lee, Y.M.; Kim, I.C.; Kanamori, A.; Choi, I.Y.; Schartl, M.; Lee, J.S. Diversity, distribution, and significance of transposable elements in the genome of the only selfing hermaphroditic vertebrate Kryptolebias marmoratus. Sci. Rep. 2017, 7, 40121. [CrossRef] [PubMed]

21. Gao, B.; Chen, W.; Shen, D.; Wang, S.; Chen, C.; Zhang, L.; Wang, W.; Wang, X.; Song, C. Characterization of autonomous families of Tc1/mariner transposons in neoteleost genomes. Mar. Genom. 2017, 34, 67-77. [CrossRef]

22. Meyer, A.; Schloissnig, S.; Franchini, P.; Du, K.; Woltering, J.M.; Irisarri, I.; Wong, W.Y.; Nowoshilow, S.; Kneitz, S.; Kawaguchi, A.; et al. Giant lungfish genome elucidates the conquest of land by vertebrates. Nature 2021, 590, 284-289. [CrossRef]

23. Wang, K.; Wang, J.; Zhu, C.; Yang, L.; Ren, Y.; Ruan, J.; Fan, G.; Hu, J.; Xu, W.; Bi, X.; et al. African lungfish genome sheds light on the vertebrate water-to-land transition. Cell 2021, 184, 1-15. [CrossRef]

24. Sotero-Caio, C.G.; Platt II, R.N.; Suh, A.; Ray, D.A. Evolution and diversity of transposable elements in vertebrate genomes. Genome Biol. Evol. 2017, 9, 161-177. [CrossRef] [PubMed]

25. Terai, Y.; Takahashi, K.; Okada, N. SINE cousins: The $3^{\prime}$-end tails of the two oldest and distantly related families of SINEs are descended from the 3'ends of LINEs with the same genealogical origin. Mol. Biol. Evol. 1998, 15, 1460-1471. [CrossRef] [PubMed]

26. Suh, A.; Churakov, G.; Ramakodi, M.P.; Platt, R.N., II; Jurka, J.; Kojima, K.K.; Caballero, J.; Smit, A.F.; Vliet, K.A.; Hoffmann, F.G.; et al. Multiple lineages of ancient CR1 retroposons shaped the early genome evolution of amniotes. Genome Biol. Evol. 2014, 7, 205-217. [CrossRef] [PubMed] 
27. Cavalcante, M.G.; Nagamachi, C.Y.; Pieczarka, J.C.; Noronha, R.C.R. Evolutionary insights in Amazonian turtles (Testudines, Podocnemididae): Co-location of 5S rDNA and U2 snRNA and wide distribution of Tc1/Mariner. Biol. Open 2020, 9, bio049817. [CrossRef]

28. Novick, P.A.; Basta, H.; Floumanhaft, M.; McClure, M.A.; Boissinot, S. The evolutionary dynamics of autonomous non-LTR retrotransposons in the lizard Anolis carolinensis shows more similarity to fish than mammals. Mol. Biol. Evol. 2009, 26, 1811-1822. [CrossRef] [PubMed]

29. Tollis, M.; Boissinot, S. Lizards and LINEs: Selection and demography affect the fate of L1 retrotransposons in the genome of the green anole (Anolis carolinensis). Genome Biol. Evol. 2013, 5, 1754-1768. [CrossRef]

30. Pasquesi, G.I.M.; Adams, R.H.; Card, D.C.; Schield, D.R.; Corbin, A.B.; Perry, B.W.; Reyes-Velasco, J.; Ruggiero, R.P.; Vandewege, M.W.; Shortt, J.A.; et al. Squamate reptiles challenge paradigms of genomic repeat element evolution set by birds and mammals. Nat. Commun. 2018, 9, 2774. [CrossRef]

31. Gilbert, C.; Hernandez, S.S.; Flores-Benabib, J.; Smith, E.N.; Feschotte, C. Rampant horizontal transfer of SPIN transposons in squamate reptiles. Mol. Biol. Evol. 2012, 29, 503-515. [CrossRef]

32. Alföldi, J.; Di Palma, F.; Grabherr, M.; Williams, C.; Kong, L.; Mauceli, E.; Russell, P.; Lowe, C.B.; Glor, R.E.; Jaffe, J.D.; et al. The genome of the green anole lizard and a comparative analysis with birds and mammals. Nature 2011, 477, 587-591. [CrossRef]

33. Kojima, K.K. A new class of SINEs with snRNA gene-derived heads. Genome Biol. Evol. 2015, 7, 1702-1712. [CrossRef] [PubMed]

34. Chong, A.Y.; Kojima, K.K.; Jurka, J.; Ray, D.A.; Smit, A.F.A.; Isberg, S.R.; Gongora, J. Evolution and gene capture in ancient endogenous retroviruses-insights from the crocodilian genomes. Retrovirology 2014, 11, 71. [CrossRef]

35. Shedlock, A.M.; Botka, C.W.; Zhao, S.; Shetty, J.; Zhang, T.; Liu, J.S.; Deschavanne, P.J.; Edwards, S.V. Phylogenomics of nonavian reptiles and the structure of the ancestral amniote genome. Proc. Natl. Acad. Sci. USA 2007, 104, 2767-2772. [CrossRef] [PubMed]

36. Ishijima, J.; Uno, Y.; Nishida, C.; Matsuda, Y. Genomic structure of the kW1 loci on the Z and W chromosomes in ratite birds: Structural changes at an early stage of W chromosome differentiation. Cytogenet. Genome Res. 2014, 142, 255-267. [CrossRef]

37. Knisbacher, B.A.; Levanon, E.Y. DNA editing of LTR retrotransposons reveals the impact of APOBECs on vertebrate genomes. Mol. Biol. Evol. 2015, 33, 554-567. [CrossRef]

38. Platt, R.N., II; Vandewege, M.W.; Ray, D.A. Mammalian transposable elements and their impacts on genome evolution. Chromosome Res. 2018, 26, 25-43. [CrossRef] [PubMed]

39. Pritham, E.J.; Feschotte, C. Massive amplification of rolling-circle transposons in the lineage of the bat Myotis lucifugus. Proc. Natl. Acad. Sci. USA 2007, 104, 1895-1900. [CrossRef]

40. Nilsson, M.A.; Janke, A.; Murchison, E.P.; Ning, Z.; Hallström, B.M. Expansion of CORE-SINEs in the genome of the tasmanian devil. BMC Genom. 2012, 13, 172. [CrossRef]

41. Gallus, S.; Hallström, B.M.; Kumar, V.; Dodt, W.G.; Janke, A.; Schumann, G.G.; Nilsson, M.A. Evolutionary histories of transposable elements in the genome of the largest living marsupial carnivore, the tasmanian devil. Mol. Evol. Biol. 2015, 32, 1268-1283. [CrossRef]

42. Thomas, J.; Phillips, C.D.; Baker, R.J.; Pritham, E.J. Rolling-Circle transposons catalyze genomic innovation in a mammalian lineage. Genome Biol. Evol. 2014, 6, 2595-2610. [CrossRef]

43. Kojima, K.K. Human transposable elements in Repbase: Genomic footprints from fish to humans. Mob. DNA 2018, 9, 2. [CrossRef] [PubMed]

44. Lander, E.S.; Linton, L.M.; Birren, B.; Nusbaum, C.; Zody, M.C.; Baldwin, J.; Devon, K.; Dewar, K.; Doyle, M.; Fitzhugh, W.; et al. Initial sequencing and analysis of the human genome. Nature 2001, 409, 860-921.

45. SanMiguel, P.; Bennetzen, J. Evidence that a recent in maize genome size was caused by the massive amplification of intergene retrotransposons. Ann. Bot. 1998, 82, 37-44. [CrossRef]

46. Bennetzen, J. Transposable element contributions to plant gene and genome evolution. Plant Mol. Biol. 2000, 42, 251-269. [CrossRef]

47. Tenaillon, M.I.; Hollister, J.D.; Gaut, B.S. A triptych of the evolution of plant transposable elements. Trends Plant Sci. 2010, 15, 471-478. [CrossRef] [PubMed]

48. Malone, C.D.; Hannon, G.J. Small RNAs as guardians of the genome. Cell 2009, 136, 656-668. [CrossRef]

49. Sun, C.; Feschotte, C.; Wu, Z.; Mueller, R.L. DNA transposons have colonized the genome of the giant virus Pandoravirus salinus. BMC Biol. 2015, 13, 38. [CrossRef] [PubMed]

50. Kumar, S.; Hedges, S.B. A molecular timescale for vertebrate evolution. Nature 1998, 392, 917-920. [CrossRef] [PubMed]

51. Pace, J.K., II; Feschotte, C. The evolutionary history of human DNA transposons: Evidence for intense activity in the primate lineage. Genome Res. 2007, 17, 422-432. [CrossRef]

52. Nishihara, H. Transposable elements as genetic accelerators of evolution: Contribution to genome size, gene regulatory network rewiring and morphological innovation. Genes Genet. Syst. 2020, 94, 269-281. [CrossRef]

53. Chuong, E.B.; Elde, N.C.; Feschotte, C. Regulatory activities of transposable elements: From conflicts to benefits. Nat. Rev. Genet. 2017, 18, 71-86. [CrossRef]

54. Feschotte, C. Transposable elements and the evolution of regulatory network. Nat. Rev. Genet. 2008, 9, 397-405. [CrossRef] [PubMed]

55. Bejerano, G.; Lowe, C.B.; Ahituv, N.; King, B.; Siepel, A.; Salama, S.R.; Rubin, E.M.; Kent, W.J.; Haussler, D. A distal enhancer and an ultraconserved exon are derived from a novel retroposon. Nature 2006, 441, 87-90. [CrossRef] [PubMed] 
56. Alföldi, J.; Lindblad-Toh, K. Comparative genomics as a tool to understand evolution and disease. Genome Res. 2013, 23, 1063-1068. [CrossRef]

57. Drongitis, D.; Aniello, F.; Fucci, L.; Donizetti, A. Roles of Transposable Elements in the Different Layers of Gene Expression Regulation. Int. J. Mol. Sci. 2019, 20, 5755. [CrossRef]

58. Huang, S.; Chen, Z.; Yan, X.; Yu, T.; Huang, G.; Yan, Q.; Pontarotti, P.A.; Zhao, H.; Li, J.; Yang, P.; et al. Decelerated genome evolution in modern vertebrates revealed by analysis of multiple lancelet genomes. Nat. Commun. 2014, 5, 5896. [CrossRef] [PubMed]

59. Smith, J.J.; Kuraku, S.; Holt, C.; Sauka-Spengler, T.; Jiang, N.; Campbell, M.S.; Yandell, M.D.; Manousaki, T.; Meyer, A.; Bloom, O.E.; et al. Sequencing of the sea lamprey (Petromyzon marinus) genome provides insights into vertebrate evolution. Nat. Genet. 2013, 45, 415-421. [CrossRef]

60. Carotti, E.; Carducci, F.; Canapa, A.; Barucca, M.; Greco, S.; Gerdol, M.; Biscotti, M.A. Transposable elements and teleost migratory behaviour. Int. J. Mol. Sci. 2021, 22, 602. [CrossRef] [PubMed]

61. Venkatesh, B.; Lee, A.P.; Ravi, V.; Maurya, A.K.; Lian, M.M.; Swann, J.B.; Ohta, Y.; Flajnik, M.F.; Sutoh, Y.; Kasahara, M.; et al. Elephant shark genome provides unique insights into gnathostome evolution. Nature 2014, 505, 174-179. [CrossRef]

62. Biscotti, M.A.; Gerdol, M.; Canapa, A.; Forconi, M.; Olmo, E.; Pallavicini, A.; Barucca, M.; Schartl, M. The lungfish transcriptome: A glimpse into molecular evolution events at the transition from water to land. Sci. Rep. 2016, 6, 21571. [CrossRef]

63. Volff, J.N.; Korting, C.; Schartl, M. Multiple lineages of the non-LTR retrotransposon Rex1 with varying success in invading fish genomes. Mol. Biol. Evol. 2000, 17, 1673-1684. [CrossRef]

64. Volff, J.N.; Körting, C.; Froschauer, A.; Sweeney, K.; Schartl, M. Non-LTR retrotransposons encoding a restriction enzyme-like endonuclease in vertebrates. J. Mol. Evol. 2001, 52, 351-360. [CrossRef] [PubMed]

65. Schneider, C.H.; Gross, M.C.; Terencio, M.L.; do Carmo, E.J.; Martins, C.; Feldberg, E. Evolutionary dynamics of retrotransposable elements Rex1, Rex3 and Rex6 in neotropical cichlid genomes. BMC Evol. Biol. 2013, 13, 152. [CrossRef]

66. Carducci, F.; Barucca, M.; Canapa, A.; Biscotti, M.A. Rex retroelements and teleosts genomes: An overview. Int. J. Mol. Sci. 2018, 19, 3653. [CrossRef]

67. Shao, F.; Wang, J.; Xu, H.; Peng, Z. FishTEDB: A collective database of transposable elements identified in the complete genomes of fish. Database 2018, 2018, 1-9. [CrossRef]

68. Amemiya, C.T.; Alföldi, J.; Lee, A.P.; Fan, S.; Philippe, H.; MacCallum, I.; Braasch, I.; Manousaki, T.; Schneider, I.; Rohneret, N.; et al. The African coelacanth genome provides insights into tetrapod evolution. Nature 2013, 496, 311-316. [CrossRef] [PubMed]

69. Forconi, M.; Chalopin, D.; Barucca, M.; Biscotti, M.A.; De Moro, G.; Galiana, D.; Gerdol, M.; Pallavicini, A.; Canapa, A.; Olmo, E.; et al. Transcriptional activity of transposable elements in coelacanth. J. Exp. Zool. B Mol. Dev. Evol. 2014, 322, 379-389. [CrossRef]

70. Metcalfe, C.J.; File'e, J.; Germon, I.; Joss, J.; Casane, D. Evolution of the Australian lungfish (Neoceratodus forsteri) genome: A major role for CR1 and L2 LINE elements. Mol. Biol. Evol. 2012, 29, 3529-3539. [CrossRef]

71. Biscotti, M.A.; Carducci, F.; Olmo, E.; Canapa, A. Vertebrate genome size and the impact of transposable elements in the genome evolution. In Evolution, Origin of Life, Concepts and Methods; Pierre, P., Ed.; Springer Nature: Cham, Switzerland, 2019 ; pp. $233-251$.

72. Voss, S.R.; Putta, S.; Walker, J.A.; Smith, J.J.; Maki, N.; Tsonis, P.A. Salamander Hox clusters contain repetitive DNA and expanded non-coding regions: A typical Hox structure for non-mammalian tetrapod vertebrates? Hum. Genom. 2013, 7, 9. [CrossRef] [PubMed]

73. Sun, C.; Shepard, D.B.; Chong, R.A.; López Arriaza, J.; Hall, K.; Castoe, T.A.; Feschotte, C.; Pollock, D.D.; Mueller, R.L. LTR retrotransposons contribute to genomic gigantism in plethodontid salamanders. Genome Biol. Evol. 2012, 40, 168-183. [CrossRef]

74. Sun, Y.-B.; Xiong, Z.-J.; Xiang, X.-Y.; Liu, S.-P.; Zhou, W.-W.; Tu, X.-L.; Zhong, L.; Wang, L.; Wu, D.-D.; Zhang, B.-L.; et al. Whole-genome sequence of the Tibetan frog Nanorana parkeri and the comparative evolution of tetrapod genomes. Proc. Natl. Acad. Sci. USA 2015, 112, E1257-E1262. [CrossRef] [PubMed]

75. Rogers, R.L.; Zhou, L.; Chu, C.; Marquez, R.; Corl, A.; Linderoth, T.; Freeborn, L.; MacManes, M.D.; Xiong, Z.; Zheng, J.; et al. Genomic takeover by transposable elements in the strawberry poison frog. Mol. Biol. Evol. 2018, 35, 2913-2927. [CrossRef] [PubMed]

76. Wang, J.; Itgen, M.W.; Wang, H.; Gong, Y.; Jiang, J.; Li, J.; Sun, C.; Sessions, S.K.; Mueller, R. Gigantic genomes can provide empirical tests of TE dynamics models-An example from Amphibians. bioRxiv 2020. [CrossRef]

77. Green, R.E.; Braun, E.L.; Armstrong, J.; Earl, D.; Nguyen, N.; Hickey, G.; Vandewege, M.W.; St John, J.A.; Capella-Gutiérrez, S.; Castoe, T.A.; et al. Three crocodilian genomes reveal ancestral patterns of evolution among archosaurs. Science 2014, 346, 1254449. [CrossRef]

78. Castoe, T.A.; Hall, K.T.; Guibotsy Mboulas, M.L.; Gu, W.; de Koning, A.P.J.; Fox, S.E.; Alexander, W.; Poole, A.W.; Vemulapalli, V.; Daza, J.M.; et al. Discovery of highly divergent repeat landscapes in snake genomes using high-throughput sequencing. Genome Biol. Evol. 2011, 3, 641-653. [CrossRef] [PubMed]

79. Castoe, T.A.; de Konig, A.P.; Hall, K.T.; Card, D.C.; Schield, D.R.; Fujita, M.K.; Ruggiero, R.P.; Degner, J.F.; Daza, J.M.; Gu, W.; et al. The Burmese python genome reveals the molecular basis for extreme adaptation in snakes. Proc. Natl. Acad. Sci. USA 2013, 110, 20645-20650. [CrossRef]

80. Kordis, D. Transposable elements in reptilian and avian (sauropsida) genomes. Cytogenet. Genome Res. 2009, 127, 94-111. [CrossRef] 
81. Suh, A.; Smeds, L.; Ellegren, H. Abundant recent activity of retrovirus-like retrotransposons within and among flycatcher species implies a rich source of structural variation in songbird genomes. Mol. Ecol. 2018, 27, 99-111. [CrossRef]

82. Richardson, S.R.; Doucet, A.J.; Kopera, H.C.; Moldovan, J.B.; Garcia-Pérez, J.L.; Moran, J.V. The influence of LINE-1 and SINE retrotransposons on mammalian genomes. Microbiol. Spectr. 2015, 3. [CrossRef]

83. Kojima, K.K. Structural and sequence diversity of eukaryotic transposable elements. Genes Genet. Syst. 2019, 94, $233-252$. [CrossRef] [PubMed]

84. Nishihara, H.; Okada, N. Retroposons: Genetic footprints on the evolutionary paths of life. Methods Mol. Biol. 2008, 422, 201-225. [PubMed]

85. Lohe, A.R.; Hartl, D.L. Autoregulation of mariner transposase activity by overproduction and dominant-negative complementation. Mol. Biol. Evol. 1996, 13, 549-555. [CrossRef] [PubMed]

86. Saha, A.; Mitchell, J.A.; Nishida, Y.; Hildreth, J.E.; Ariberre, J.A.; Gilbert, W.V.; Garfinkel, D.J. A trans-dominant form of gag restricts Ty1 retrotransposition and mediates copy number control. J. Virol. 2015, 89, 3922-3938. [CrossRef]

87. Muñoz-Lopez, M.; Garcia-Perez, J.L. DNA transposons: Nature and applications in genomics. Curr. Genom. 2010, 11, 115-128. [CrossRef]

88. Imbeault, M.; Helleboid, P.-Y.; Trono, D. KRAB zinc-finger proteins contribute to the evolution of gene regulatory networks. Nature 2017, 543, 550-554. [CrossRef]

89. Yang, P.; Wang, Y.; Macfarlan, T.S. The role of KRAB-ZFPs in transposable element repression and mammalian evolution. Trends Genet. 2017, 33, 871-881. [CrossRef]

90. Ecco, G.; Imbeault, M.; Trono, D. KRAB zinc finger proteins. Development 2017, 144, 2719-2729. [CrossRef]

91. Jones, P.A. Functions of DNA methylation: Islands, start sites, gene bodies and beyond. Nat. Rev. Genet. 2012, 13, 484-492. [CrossRef] [PubMed]

92. Karimi, M.M.; Goyal, P.; Maksakova, I.A.; Bilenky, M.; Leung, D.; Tang, J.X.; Shinkai, Y.; Mager, D.L.; Rangasamy, D. Distinctive patterns of epigenetic marks are associated with promoter regions of mouse LINE-1 and LTR retrotransposons. Mob. DNA 2013, 4, 27.

93. Ender, C.; Meister, G. Argonaute proteins at a glance. J. Cell Sci. 2010, 123, 1819-1823. [CrossRef]

94. Slotkin, R.K.; Martienssen, R. Transposable elements and the epigenetic regulation of the genome. Nat. Rev. Genet. 2007, 8, 272-285. [CrossRef]

95. Czech, B.; Hannon, G.J. One loop to rule them all: The ping-pong cycle and piRNA guided silencing. Trends Biochem. Sci. 2016, 41, 324-337. [CrossRef] [PubMed]

96. Dechaud, C.; Volff, J.-N.; Schartl, M.; Naville, M. Sex and the TEs: Transposable elements in sexual development and function in animals. Mob. DNA 2019, 10, 42. [CrossRef] [PubMed]

97. Le Thomas, A.; Fejes, K.T.; Aravin, A.A. To be or not to be a piRNA: Genomic origin and processing of piRNAs. Genome Biol. 2014, 15, 204. [CrossRef] [PubMed]

98. Deniz, O.; Frost, J.M.; Branco, M.R. Regulation of transposable elements by DNA modification. Nat. Rev. Genet. 2019, $20,417-431$. [CrossRef] [PubMed]

99. Barau, J.; Teissandier, A.; Zamudio, N.; Roy, S.; Nalesso, V.; Hérault, Y.; Guillou, F.; Bourchis, D. The DNA methyltransferase DNMT3C protects male germ cells from transposon activity. Science 2016, 354, 909-912. [CrossRef] [PubMed]

100. Jangam, D.; Feschotte, C.; Betran, E. Transposable element domestication as an adaptation to evolutionary conflicts. Trends Genet. 2017, 33, 817-831. [CrossRef] [PubMed]

101. Chiu, Y.L.; Greene, W.C. The APOBEC3 cytidine deaminases: An innate defensive network opposing exogenous retroviruses and endogenous retroelements. Annu. Rev. Immunol. 2008, 26, 317-353. [CrossRef]

102. Sharavanan, V.J.; Sivaramakrishnan, M.; Sivarajasekar, N.; Senthilrani, N.; Kothandan, R.; Dhakal, N.; Sivamani, S.; Show, P.L.; Awual, M.R.; Naushad, M. Pollutants inducing epigenetic changes and diseases. Environ. Chem. Lett. 2019, 18, 325-343. [CrossRef]

103. Zeh, D.W.; Zeh, J.A.; Ishida, Y. Transposable elements and an epigenetic basis for punctuated equilibria. Bioessays 2009, 31, 715-726. [CrossRef]

104. Casacuberta, E.; Gonzalez, J. The impact of transposable elements in environmental adaptation. Mol. Ecol. 2013, 22, 1503-1517. [CrossRef]

105. Kemp, J.R.; Longworth, M.S. Crossing the LINE Toward Genomic Instability: LINE-1 retrotransposition in cancer. Front. Chem. 2015, 3, 68. [CrossRef] [PubMed]

106. Franchini, L.F.; López-Leal, R.; Nasif, S.; Beati, P.; Gelman, D.M.; Low, M.J.; de Souza, F.J.; Rubinstein, M. Convergent evolution of two mammalian neuronal enhancers by sequential exaptation of unrelated retroposons. Proc. Natl. Acad. Sci. USA 2011, 108, 15270-15275. [CrossRef] [PubMed]

107. Miousse, I.R.; Chalbot, M.-C.G.; Lumen, A.; Ferguson, A.; Kavouras, I.G.; Koturbash, I. Response of transposable elements to environmental stressors. Mutat. Res. 2015, 765, 19-39. [CrossRef] [PubMed]

108. Kim, K.Y.; Kim, D.S.; Lee, S.K.; Lee, I.K.; Kang, J.H.; Chang, Y.S.; Jacobs, D.R.; Steffes, M.; Lee, D.H. Association of low-dose exposure to persistent organic pollutants with global DNA hypomethylation in healthy Koreans, Environ. Health Perspect. 2010, 118, 370-374. [CrossRef] [PubMed] 
109. Wright, R.O.; Schwartz, J.; Wright, R.J.; Bollati, V.; Tarantini, L.; Park, S.K.; Hu, H.; Sparrow, D.; Vokonas, P.; Baccarelli, A. Biomarkers of lead exposure and DNA methylation within retrotransposons. Environ. Health Perspect. 2010, 118, 790-795. [CrossRef] [PubMed]

110. Karimi, A.; Madjd, Z.; Habibi, L.; Akrami, S.M. Exposure of hepatocellular carcinoma cells to low-level As2O3 causes an extra toxicity pathway via L1 retrotransposition induction. Toxicol. Lett. 2014, 229, 111-117. [CrossRef]

111. Habibi, L.; Shokrgozar, M.A.; Tabrizi, M.; Modarressi, M.H.; Akrami, S.M. Mercury specifically induces LINE-1 activity in a human neuroblastoma cell line. Mutat. Res. 2014, 759, 9-20. [CrossRef]

112. Kazazian, H.H., Jr.; Wong, C.; Youssoufian, H.; Scott, A.F.; Phillips, D.G.; Antonarakis, S.E. Haemophilia A resulting from de novo insertion of L1 sequences represents a novel mechanism for mutation in man. Nature 1988, 332, 164-166. [CrossRef]

113. Beck, C.R.; Garcia-Perez, J.L.; Badge, R.M.; Moran, J.V. LINE-1 elements in structural variation and disease. Annu. Rev. Genom. Hum. Genet. 2011, 12, 187-215. [CrossRef]

114. Hancks, D.C.; Kazazian, H.H., Jr. Active human retrotransposons: Variation and disease. Curr. Opin. Genet. Dev. 2012, $22,191-203$. [CrossRef] [PubMed]

115. Scott, E.C.; Gardner, E.J.; Masood, A.; Chuang, N.T.; Vertino, P.M.; Devine, S.E. A hot L1 retrotransposon evades somatic repression and initiates human colorectal cancer. Genome Res. 2016, 26, 745-755. [CrossRef] [PubMed]

116. Criscione, S.W.; Zhang, Y.; Thompson, W.; Sedivy, J.M.; Neretti, N. Transcriptional landscape of repetitive elements in normal and cancer human cells. BMC Genom. 2014, 15, 1-17. [CrossRef] [PubMed]

117. Lee, E.; Iskow, R.; Yang, L.; Gokcumen, O.; Haseley, P.; Luquette, L.J., III; Lohr, J.G.; Harris, C.C.; Ding, L.; Wilson, R.K.; et al. Landscape of somatic retrotransposition in human cancers. Science 2012, 337, 967-971. [CrossRef] [PubMed]

118. Solyom, S.; Ewing, A.D.; Rahrmann, E.P.; Doucet, T.; Nelson, H.H.; Burns, M.B.; Harris, R.S.; Sigmon, D.F.; Casella, A.; Erlanger, B.; et al. Extensive somatic L1 retrotransposition in colorectal tumors. Genome Res. 2012, 22, 2328-2338. [CrossRef] [PubMed]

119. Van Meter, M.V.; Kashyap, M.; Rezazadeh, S.; Geneva, A.J.; Morello, T.D.; Seluanov, A.; Gorbunova, V. SIRT6 represses LINE1 retrotransposons by ribosylating KAP1 but this repression fails with stress and age. Nat. Commun. 2014, 5, 5011. [CrossRef]

120. Bundo, M.; Toyoshima, M.; Okada, Y.; Akamatsu, W.; Ueda, J.; Nemoto-Miyauchi, T.; Sunaga, F.; Toritsuka, M.; Ikawa, D.; Kakita, A.; et al. Increased 11 retrotransposition in the neuronal genome in schizophrenia. Neuron 2014, 81, 306-313. [CrossRef]

121. Li, W.; Jin, Y.; Prazak, L.; Hammell, M.; Dubnau, J. Transposable elements in TDP-43-mediated neurodegenerative disorders. PLoS ONE 2012, 7, e44099. [CrossRef]

122. Reilly, M.T.; Faulkner, G.J.; Dubnau, J.; Ponomarev, I.; Gage, F.H. The role of transposable elements in health and diseases of the central nervous system. J. Neurosci. 2013, 33, 17577-17586. [CrossRef]

123. Hunter, R.G.; Gagnidze, K.; McEwen, B.S.; Pfaff, D.W. Stress and the dynamic genome: Steroids, epigenetics, and the transposome. Proc. Natl. Acad. Sci. USA 2015, 112, 6828-6833. [CrossRef]

124. Yao, B.; Cheng, Y.; Wang, Z.; Li, Y.; Chen, L.; Huang, L.; Zhang, W.; Chen, D.; Wu, H.; Tang, B.; et al. DNA N6-methyladenine is dynamically regulated in the mouse brain following environmental stress. Nat. Commun. 2017, 8, 1122. [CrossRef] [PubMed]

125. Hunter, R.G.; Murakamia, G.; Dewellc, S.; Seligsohnb, M.; Bakerb, M.E.R.; Datsond, N.A.; McEwenb, B.S.; Pfaff, D.W. Acute stress and hippocampal histone $\mathrm{H} 3$ lysine 9 trimethylation, a retrotransposon silencing response. Proc. Natl. Acad. Sci. USA 2012, 109, 17657-17662. [CrossRef]

126. Hunter, R.G.; McEwen, B.S.; Pfaff, D.W. Environmental stress and transposon transcription in the mammalian brain. Mob. Genet. Elem. 2013, 3, e24555. [CrossRef] [PubMed]

127. Mariner, P.D.; Walters, R.D.; Espinoza, C.A.; Drullinger, L.F.; Wagner, S.D.; Kugel, J.F.; Goodrich, J.A. Human Alu RNA is a modular transacting repressor of mRNA transcription during heat shock. Mol. Cell. 2008, 29, 499-509. [CrossRef] [PubMed]

128. Hummel, B.; Hansen, E.C.; Yoveva, A.; Aprile-Garcia, F.; Hussong, R.; Sawarkar, R. The evolutionary capacitor HSP90 buffers the regulatory effects of mammalian endogenous retroviruses. Nat. Struct. Mol. Biol. 2017, 24, 234-244. [CrossRef]

129. Zovoilis, A.; Cifuentes-Rojas, C.; Chu, H.-P.; Hernandez, A.J.; Lee, J.T. Destabilization of B2 RNAby EZH2 Activates the Stress Response. Cell 2016, 167, 1788-1802. [CrossRef]

130. Hovarth, V.; Merenciano, M.; Gonzalez, J. Revisiting the relationship between transposable elements and the eukaryotic stress response. Trends Genet. 2017, 33, 11.

131. Wolff, G.L.; Kodell, R.L.; Moore, S.R.; Cooney, C.A. Maternal epigenetics and methyl supplements affect agouti gene expression in Avy/a mice. FASEB J. 1998, 12, 949-957. [CrossRef]

132. Morgan, H.D.; Sutherland, H.G.; Martin, D.I.; Whitelaw, E. Epigenetic inheritance at the agouti locus in the mouse. Nat. Genet. 1999, 23, 314-318. [CrossRef]

133. Waterland, R.A.; Jirtle, R.L. Transposable elements: Targets for early nutritional effects on epigenetic gene regulation. Mol. Cell. Biol. 2003, 23, 5293-5300. [CrossRef] [PubMed]

134. Jiménez-Chillarón, J.C.; Díaz, R.; Martínez, D.; Pentinat, T.; Ramón-Krauel, M.; Ribó, S.; Plösch, T. The role of nutrition on epigenetic modifications and their implications on health. Biochimie 2012, 94, 2242-2263. [CrossRef] [PubMed]

135. Dolinoy, D.C.; Huang, D.; Jirtle, R.L. Maternal nutrient supplementation counteracts bisphenol A-induced DNA hypomethylation in early development. Proc. Natl. Acad. Sci. USA 2007, 104, 13056-13061. [CrossRef] [PubMed]

136. Zempleni, J.; Chew, Y.C.; Bao, B.; Pestinger, V.; Wijeratne, S.S.K. Repression of transposable elements by histone biotinylation. J. Nutr. 2009, 139, 2389-2392. [CrossRef] 
137. Kuroishi, T.; Rios-Avila, L.; Pestinger, V.; Wijeratne, S.S.K.; Zempleni, J. Biotinylation is a natural, albeit rare, modification of human histones. Mol. Genet. Metab. 2011, 104, 537-545. [CrossRef] [PubMed]

138. Pflieger, A.; Teguo, P.W.; Papastamoulis, Y.; Chaignepain, S.; Subra, F.; Munir, S.; Delelis, O.; Lesbats, P.; Calmels, C.; Andreola M.-L.; et al. Natural stilbenoids isolated from grapevine exhibiting inhibitory effects against HIV-1 integrase and eukaryote MOS1 transposase in vitro activities. PLoS ONE 2013, 8, e81184. [CrossRef]

139. Agodi, A.; Barchitta, M.; Quattrocchi, A.; Maugeri, A.; Canto, C.; Marchese, A.E.; Vinciguerra, M. Low fruit consumption and folate deficiency are associated with LINE-1 hypomethylation in women of a cancer-free population. Genes Nutr. 2015, 10, 30. [CrossRef]

140. Barchitta, M.; Maugeri, A.; Quattrocchi, A.; Barone, G.; Mazzoleni, P.; Catalfo, A.; De Guidi, G.; Iemmolo, M.G.; Crimi, N.; Agodi, A. Mediterranean diet and particulate matter exposure are associated with LINE-1 methylation: Results from a cross-sectional study in women. Front. Genet. 2018, 9, 514. [CrossRef]

141. Green, C.D.; Huang, Y.; Dou, X.; Yang, L.; Liu, Y.; Han, J.-D.J. Impact of dietary interventions on noncoding RNA networks and mRNAs encoding chromatin-related factors. Cell Rep. 2017, 18, 2957-2968. [CrossRef] 